\title{
Economic losses due to live weight shrinkage and mortality during the broiler transport
}

\author{
Yılmaz ARAL, Mehmet Saltuk ARIKAN, Ahmet Cumhur AKIN, Çağla Yüksel KAYA KUYULULU, \\ Seyit Can GÜLOĞLU, Engin SAKARYA
}

Department of Animal Health Economics and Management, Faculty of Veterinary Medicine, Ankara University, Ankara/Turkey.

Summary: The aim of this study is to determine the economic impact of live weight losses and mortality due to transport of broilers, from farms under contract production to the slaughterhouse and to analyse the total cost differences between different groups of total loading and transport durations in Turkey. Data concerning 846 transports from an integration's different farms to its slaughterhouse in May 2012 were collected and examined thoroughly for the purpose of this study. Data were clustered into 6 different groups according to their total loading and transport durations. These groups were defined as; group I 0-120 min, group II 121-240 min, group III 241-360 min, group IV 361-480 min, group V 481-600 min, group VI 600 min and more. Mortality rate in each group was found to be $0.29 \%, 0.38 \%, 0.40 \%, 0.43 \%, 0.42 \%$, and $0.46 \%$, respectively. On the other hand, average live weight loss during transport in each group was determined to be $4.33 \%, 4.95 \%, 5.55 \%, 5.73 \%, 6.02 \%$ and $6.63 \%$, in the given order. The results of the analyse show that the average slaughtering age of the transported chickens are 42 days, average loading density in trucks are 3154 chickens per truck, and the average economic loss due to live weight loss and mortality per transport is TL 136.29 . Economic loss due to the transport of 2.669 .059 chickens was calculated as TL 115.300 in total. As a result, this study clearly shows that the sector needs more diversified scientific researches on the topic, in particular when the increase in production capacity of the sector in recent years, the localisation and distribution of farms of integrations, and apart from the transport duration the impact of distance, seasonal conditions, loading density, road characteristics, type of the vehicle and its velocity on losses due to transport are taken into consideration.

Key words: Broiler, cost, live weight loss, mortality, transport.

\section{Etlik piliçlerin taşınması sırasında canlı ağırlık fireleri ve mortalite nedeniyle oluşan ekonomik kayıplar}

Özet: Bu çalışma kapsamında, Türkiye'de piliç eti sektöründe sözleşmeli üretim modeli çerçevesinde faaliyet gösteren kümeslerden kesimhaneye yapılan broiler nakillerinde taşıma esnasında oluşan canlı ağırlık kayıpları ve mortaliteye bağlı ekonomik etkilerin tespit edilmesi ile yükleme ve taşıma süreleri bakımından belirlenen gruplar arasındaki toplam maliyet farklılıklarının analizinin yapılması amaçlanmıştır. Bu kapsamda Mayıs 2012 tarihi itibariyle bir entegrasyona bağlı olan kümeslerden tek bir kesimhaneye yapılan toplam 846 adet taşıma işlemine ait veriler toplanarak detaylı şekilde incelenmiştir. Bilgisayar ortamında değerlendirilen veriler yükleme ve taşıma süreleri üzerinden 6 farklı gruba ayrılmıştır. Bu gruplar; I.grup 0-120 dakika, II. grup 121240 dakika, III. Grup 241-360 dakika, IV. grup 361-480 dakika, V.grup 481-600 dakika, VI. grup 600 dakika ve üzeri olarak ölçeklendirilmiştir. Yapılan analiz sonucunda gruplar itibariyle mortalite oranları sırası ile; \% $0.29, \% 0.38, \% 0.40, \% 0.43, \% 0.42$ ve \% 0.46 olarak tespit edilmiştir. Diğer taraftan, söz konusu gruplarda ele alınan taşımalar sırasında oluşan ortalama canlı ağırlık kayıpları yine sırasıyla; \% 4.33, \% 4.95, \% 5.55, \% 5.73, \% 6.02 ve \% 6.63 olarak belirlenmiştir. Çalışmada nakli gerçekleştirilen piliçlerin ortalama kesim yaşı 42 gün, taşıma araçlarındaki ortalama yükleme yoğunluğu 3154 adet, gruplar arasında değişmekle birlikte canlı ağırlık firesi ve mortalite nedeniyle taşıma başına ortalama ekonomik kayıp 136,29 TL olarak saptanmıştır. Ayrıca toplam 2.669.059 adet pilicin kesimhaneye sevki sırasında oluşan toplam ekonomik kayıp 115.300 TL düzeyinde hesaplanmıştır. Sonuç olarak; sektörün son dönemdeki üretim kapasitesi artışı, entegrasyona bağlı kümeslerin lokalizasyonu ve dağınık yapıda bulunması, nakile bağlı kayıplar üzerinde taşıma süresi dışında mesafe, mevsimsel şartlar, yükleme yoğunluğu, yol özellikleri, aracın türü ve sürati gibi faktörlerinde etkili olması bu konu üzerinde yapılacak bilimsel araştırmaların, sayı ve kapsam yönünden geliştirilmesi ve çeşitlendirilmesi gerektiğini düşündürmektedir.

Anahtar sözcükler: Canlı ağırlık kaybı, etlik piliç, maliyet, mortalite, taşıma.

\section{Introduction}

Poultry meat sector in Turkey gained acceleration in 1980 s and has made a rapid progress since then as it managed to integrate industry into animal production. With the investments made by poultry firms, the sector has become one of the leaders in the world in terms of 

Engin Sakarya

both the achieved in the quality of broiler meat and the level of technology and caring and feeding standards used in the production process. Despite the achievements made by the sector, the most important problems that need to solved include, among others, reduction of production costs, planning of the volume of production and sectoral growth, and enhancement of the level of consumption in line with the preferences of consumers in national and foreign markets.

Avoiding losses that arise from practical mistakes in the management and production organization of the enterprises in the poultry sector is of great importance for producer companies in the sense of achieving profit maximization and competitive advantage. Many mistakes and deficiencies in production process, which lead to economic losses for producer companies, take place in the pre-slaughter stages and particularly during the transport of broilers from poultry farms to slaughter houses $(11,13,19)$.

Transportation is one of the fundamental elements of the poultry industry and has a multi-factor structure. Particularly, the microclimatic conditions in transportation vehicles are considered to be the most significant factor that causes losses and deaths due to hot and cold stress during transportation. Additionally, size, age and health condition of broilers and managerial factors are important as well $(5,13,14)$.

Stress-causing incidents and practices during the catching, loading, transportation and waiting stages in the pre-slaughter period may have adverse impacts on the quality of meat and animal welfare, and may increase pre-slaughter mortality rate $(1,21)$. On the other hand, extended duration of transportation prior to slaughter has negative impacts on carcass yield and economic production due to increased mortality rate and rate of live weight shrinkage (3).

Among major factors that affect the rate of mortality during the transportation of broilers prior to slaughter are ambient temperature and humidity, period during the day, density of broilers on the trucks and in the cages, season, distance between the poultry farm and slaughterhouse, and duration of transportation (17).

Broilers that reach slaughter weight in broiler breeding facilities are transported by vehicles provided by the integrated company. They are caught and put into cages on trucks by loading workers and transported to poultry slaughter houses by land. These broilers on the vehicles weighed in the animal admission section at the entrance of the poultry slaughterhouse are conveyed to the hangers on the slaughter line after a waiting period that depends on the order of slaughter, and become ready for slaughter process.

This study aims to identify the change of mortality rate and live weight shrinkage during the stage of transportation from poultry farms that carry out contract production within the scope of integration to slaughter houses, including the loading stage, as well as the economic impact and cost differences between groups by the duration of transportation.

\section{Materials and Methods}

The material of the study consists of the data and transportation records related to 2,669,059 broilers brought from contract broiler breeding poultry enterprises affiliated with an integrated poultry company based in Turkey to the company's central slaughter house in 846 transportation occasions during May 2012. Among the main data obtained and analysed are the facility details, exit time of vehicles from farms, live weight of broilers in cages, slaughter age of broilers, number of broilers transported in each transportation vehicle, total weight of the transportation vehicle at the animal admission section of the slaughterhouse, total duration of loading and transportation, number of deaths during transportation, time of slaughter and waiting time.

The data collected and entered into computer for analysis are classified into 6 groups by the duration of transportation in order to identify the live weight shrinkage and rate of mortality during broiler transportation.

According to this classification by total duration of loading and transportation between the poultry farms and the slaughterhouse, group I has a duration of 0-120 minutes, group II 121-240 minutes, group III 241-360 minutes, group IV 361-480 minutes, group V 481-600 minutes and group VI 600 minutes and above.

In consequence of the analysis conducted to attain the objective of the study, mortality rates (\%) and live weight losses $(\%)$ for each transportation group as well as average and total costs of losses (TL) were calculated. Market live weight purchase price (breeder price) for the relevant period was used in the calculation of economic losses due to mortality and live weight losses. Considering the increase in the volume of production of chicken meat and total number of slaughtered animals in the country, inferences are made regarding the sectoral impacts of transportation.

\section{Results}

The study reveals that in 846 transportation occasions between poultry farms affiliated with one integration and the slaughter house the average slaughter age of broilers $(2,669,059$ in total) is 42 days and the average number of broilers loaded in one transportation (density in the vehicle) is 3,154. Findings on the mortality rates during transportation by each group are given in Table 1.

As can be seen in Table 1, 10,925 broilers died throughout all transportations and the mortality rate is 
Table 1. Losses due to mortality rates during broiler transport.

Tablo 1. Broiler taşıma esnasında mortaliteye bağlı kayıplar.

\begin{tabular}{cccccc}
\hline Groups & $\begin{array}{c}\text { Number of } \\
\text { Animals } \\
\text { Transported }\end{array}$ & $\begin{array}{c}\text { Number of } \\
\text { Animals } \\
\text { Slaughtered }\end{array}$ & $\begin{array}{c}\text { Mortality Rate } \\
(\%)\end{array}$ & $\begin{array}{c}\text { Number of Animals } \\
\text { Deaths During the } \\
\text { Transportation }\end{array}$ & $\begin{array}{c}\text { Average Live } \\
\text { Weight of Animals } \\
(\mathrm{kg})\end{array}$ \\
\hline I. & 113.079 & 112.747 & 0.29 & 332 & 2,285 \\
II. & 754.869 & 751.996 & 0.38 & 2.873 & 2,421 \\
III. & 706.113 & 703.237 & 0.40 & 2.876 & 2,528 \\
IV. & 523.947 & 521.645 & 0.43 & 2.302 & 2,558 \\
V. & 253.729 & 252.662 & 0.42 & 1.067 & 2,550 \\
VI. & 317.322 & 315.847 & 0.46 & 1.475 & 2,500 \\
Total & 2.669 .059 & 2.658 .134 & 0.41 & 10.925 & - \\
\hline
\end{tabular}

Table 2. Live weight losses of broiler chickens during the transport.

Tablo 2. Broiler taşıma sırasında oluşan canlı ağırlık kayıpları.

\begin{tabular}{|c|c|c|c|c|c|c|c|}
\hline \multirow{2}{*}{ Groups } & \multirow{2}{*}{$\begin{array}{c}\text { Loading }+ \\
\text { Transport } \\
\text { Durations (min.) }\end{array}$} & \multirow{2}{*}{$\begin{array}{l}\text { Number of } \\
\text { Transports }\end{array}$} & \multirow{2}{*}{$\begin{array}{l}\text { Exit Weight of } \\
\text { Vehicles from } \\
\text { Farms (kg) }\end{array}$} & \multirow{2}{*}{$\begin{array}{l}\text { Slaughterhouse } \\
\text { Entrance Weight } \\
\text { of Vehicles (kg) }\end{array}$} & \multicolumn{3}{|c|}{ Live Weight Loss (\%) } \\
\hline & & & & & Min & Max & Average \\
\hline I. & $0-120$ & 37 & 258.882 & 247.840 & 2.38 & 7.12 & 4.33 \\
\hline II. & $121-240$ & 250 & 1.805 .708 & 1.715 .580 & 2.13 & 9.78 & 4.95 \\
\hline III. & $241-360$ & 236 & 1.772 .050 & 1.675 .360 & 2.17 & 9.74 & 5.55 \\
\hline IV. & $361-480$ & 169 & 1.321 .346 & 1.248 .640 & 3.38 & 9.73 & 5.73 \\
\hline V. & $481-600$ & 76 & 635.415 & 598.100 & 3.58 & 12.06 & 6.02 \\
\hline VI. & $600+$ & 78 & 781.682 & 731.440 & 3.89 & 12.27 & 6.63 \\
\hline Total & - & 846 & 6.575 .083 & 6.216 .960 & - & - & - \\
\hline Average & 349 & - & - & - & 2.13 & 12.27 & 5.43 \\
\hline
\end{tabular}

Table 3. Economic losses due to live weight shrinkage and mortality during broiler transport.

Tablo 3. Broiler taşımasında canlı ağırlık firesi ve mortaliteye bağlı ekonomik kayıplar.

\begin{tabular}{cccccc}
\hline Groups & $\begin{array}{c}\text { Total Live Weight } \\
\text { Loss (kg) } \\
\text { (I) }\end{array}$ & $\begin{array}{c}\text { Total Losses Due to } \\
\text { Mortality (kg) } \\
\text { (II) }\end{array}$ & $\begin{array}{c}\text { Total Losses } \\
(\mathrm{kg}) \\
(\mathrm{I}+\mathrm{II})\end{array}$ & $\begin{array}{c}\text { Total Economic } \\
\text { Losses (TL) }\end{array}$ & $\begin{array}{c}\text { Average Economic } \\
\text { Loss Per Transport } \\
\text { (Occasion/TL) }\end{array}$ \\
\hline I. & 11.042 & 758 & 11.800 & 3.540 & 95,67 \\
II. & 90.128 & 6.955 & 97.083 & 29.124 & 116,49 \\
III. & 96.690 & 7.270 & 103.960 & 31.188 & 132,15 \\
IV. & 72.706 & 5.888 & 78.594 & 23.578 & 139,51 \\
V. & 36.254 & 2.720 & 38.974 & 11.692 & 153,84 \\
VI. & 50.242 & 3.687 & 53.929 & 16.178 & 207,41 \\
Total & 357.062 & 27.278 & 384.340 & 115.300 & - \\
\hline
\end{tabular}

* In this calculation, the live weight purchase price (breeder price) charged by the integration for the relevant period is accepted to be $30 \mathrm{kr}$ per $\mathrm{kg}$. ** $1 \mathrm{USD}=1.80 \mathrm{TL}$ in May 2012.

found to be $0.41 \%$. According to the classification made based on the loading and transportation duration of broilers, the lowest mortality rate, $0.29 \%$, is in group I, which has a total transportation duration of $0-120$ minutes, and the highest mortality rate, $0.46 \%$, is in group VI, which has a total transportation duration of 600 minutes and above.

Findings obtained concerning the live weight shrinkage during the transportation of broilers are given in Table 2.
On examining Table 2, it is seen that the average loading and transportation duration of all transportation occasions analysed in this study is 349 minutes, the average live weight shrinkage in broilers is $5.43 \%$, and that the live weight shrinkages increase as the duration of transportation increases (4.33\%-6.63\%). Live weight shrinkages due to changes in loading and transportation conditions were found to be between $2.13 \%$ and $12.27 \%$.

Economic losses due to live weight shrinkage and mortality calculated for each group are given in Table 3 . 
As can be seen in Table 3, the average economic loss due to live weight shrinkage and mortality for each unit of transportation is TL 95.67 in group I, TL 116.49 in group II, TL 132.15 in group III, TL 139.51 in group IV, TL 153.84 in group V, and TL 207.41 in group VI. The total economic loss in all transportation occasions is calculated to be TL 115,300.

\section{Discussion and Conclusion}

Practices in each step of the process between broiler farms and poultry slaughterhouses significantly affect the live weight shrinkage and mortality rate, and cause economic losses. This adversely impacts the revenues of integrated companies that basically aim for high-capacity and sustainable production as well as of contract broiler producers.

In some studies on the impact of transportation on broilers, the major factors affecting the live weight shrinkages and mortalities that occur between farms and slaughterhouses are the method of catching $(7,9)$, distance of transportation $(11,16,18)$, duration of transportation $(2,3,11,19)$, waiting time in the animal admission section $(2,11)$, time of transportation during the day (2), animal density per cage $(2,4)$, seasonal effect $(6,12,16,18)$, daily temperature $(20)$ and weather conditions (4).

In this study, which aims to identify the change in live weight shrinkages and mortality during broiler transportation in Turkey taking into account the loading and transportation durations prior to slaughter, the average live weight shrinkage in all transportations was found to be $5.43 \%$ and the mortality rate $0.41 \%$. It was found that these rates, which increase as the duration of transportation increases, vary between $4.33 \%-6.33 \%$ and $0.29 \%-0.46 \%$, respectively.

A study that deals with transportations to a slaughter house in Sao Paulo, Brazil in 2006 reports that the average mortality rate of broilers during processes prior to slaughter is $0.42 \%$ in summer, $0.39 \%$ in spring, $0.28 \%$ in winter and $0.23 \%$ in autumn (17). The said study also reports that the loading density per truck is 3,337 broilers, the average transportation distance is 120 $\mathrm{km}$ (min: $24 / \max : 242 \mathrm{~km}$ ) and the average duration of transportation is 90 minutes (min: $20 \mathrm{~min}$. / max: $4 \mathrm{hrs}$.).

In a study conducted in Italy between September 2002 and May 2003, mortality rate and transportation duration of broilers in 321 flocks, the slaughter age of which varies between 38 and 55 days, are examined in 3 groups (Group $1<3.5$ hours, Group 2: 3.5-5 hours, Group 3: $>5$ hours), and mortality rates of the groups are $0.24 \%, 0.41 \%$ and $0.45 \%$, respectively, whereas the live weight shrinkages of the groups are $1.27 \%, 1.87 \%$ and $2.09 \%$, respectively. The study also states that the average live weight shrinkage for each hour of transportation is $0.23 \%(3)$.
In a study conducted on 1,907 enterprises in Netherlands and Germany between 2000 and 2001, the average mortality rate in broilers transported to slaughter house was found to be $0.46 \%$. The study reports that the most important factors affecting the change in the mortality rate in the pre-slaughter stage are loading density, transportation time, and waiting time prior to slaughter (11).

In another study, the mortality rate (during transportation) in 1,266,000 broilers slaughtered in 33 broiler slaughter houses between 2001 and 2005 was found to be $0.35 \%$ in Italy. This study reports that seasonal conditions have a significant impact on the mortality rate (12).

Another study conducted in the Czech Republic between 1997 and 2004 researched the impact of broiler transportation distance and seasons on the mortality rate during transportation. The study found that the mortality rate during transportation was $0.247 \%$. The same study reported that the mortality rate in enterprises whose distance to the slaughter house was $50 \mathrm{~km}$ at most was $0.146 \%$ and the mortality rate in those which are at least $300 \mathrm{~km}$ away was $0.862 \%$. Furthermore, the impact of season on mortality rate was reported to be the highest in summer months (June, July and August) and winter months (December, January, February) (16).

An experimental study on the impacts of cold weather conditions on broiler transportation in Canada found that the average live weight shrinkage in broilers transported at $-5,-10$ and $-15{ }^{\circ} \mathrm{C}$ varied between 4.8 $5.0 \%(14)$.

Another study examining the transportation of 1,090,733 broilers from 194 enterprises to slaughter house in Manitoba, Canada in 198 loading operations in spring and summer calculated the average mortality rate to be $0.346 \%$ (6).

A study researching the factors affecting the mortality rate in broilers of 404 enterprises in France in 2005 during their transportation to the slaughter house found the mortality rate as $0.18 \%$ and reported that the method of catching, density in the transportation vehicle and climatic conditions were the major factors affecting the mortality rate (4). Another study conducted in the $\mathrm{UK}$, the mortality rate during broiler transportation from 150 enterprises to slaughter houses was found to be $0.12 \%(8)$.

A study conducted in the U.S.A reported that the height of the cages used in transportation vehicles did not affect the live weight shrinkage, and that out of an average live weight shrinkage of $4.2 \%$ during broiler transportation, a loss of $1.8 \%$ was due to excreta (15). In another study, the average live weight shrinkage in consequence of the transportation of 39-day old and 53day old broilers for 6 hours and a waiting period of 4 hours was found to be $5.8 \%$ and $6.2 \%$, respectively (10). 
The study reveals that the economic loss due to live weight shrinkage and mortality during transportation gradually increases between groups, depending on the extended duration of transportation, and the average loss for each transportation occasion varies between TL 95.67 and TL 207.41. If the economic loss calculated for 846 transportations in total (TL 115,300) is generalized for the entire country, the total economic loss in Turkey is estimated to be around TL 40 billion. However, it is considered that this loss could be reduced to half if integrated companies can plan their live production around slaughter houses and within short transportation distances.

An example analysis on the findings of the study may be as follows: While the total economic loss of a broiler breeding enterprise with a production capacity of 20,000 heads, calculated for the transportation group I, is TL 606.66, its loss in group VI, which represents the longest transportation distance, may reach TL 1,315.22 (difference: TL 708.56).

Therefore, it would be useful if transportation costs are addressed by producers and integrated companies from the perspective of economical use of national resources and if an approach is adopted, which aims to minimize the transportation and marketing costs as well as selecting the optimum location of establishment and centralising the production prior to making poultry farm and slaughterhouse investments.

It is considered that scientific studies to be conducted on pre-slaughter stages, particularly transportation, in Turkey and improvements in the number and scope of researches may steer sectoral policies because the production capacity of the poultry sector has been recently increasing, farms of integrated facilities have a localized and dispersed structure, and numerous factors other than the duration of transportation affect the level of losses during transportation, such as distance, seasonal conditions, loading density, road quality, type of vehicle and its velocity.

\section{References}

1. Adzitey F (2011): Effect of pre-slaughter animal handling on carcass and meat quality. Int. Food Res. J., 18, 485491.

2. Bayliss PA, Hinton MH (1990): Transportation of poultry with special reference to mortality rates. Appl.Animal Behaviour Sci., 28, 93-118.

3. Bianchi M, Petracci M, Cavani C (2005): Effects of transport and lairage on mortality, liveweight loss and carcass quality in broiler chickens. Ital.J.Anim.Sci., 4, 516-518.

4. Chauvin C, Hillion S, Balaine L, Michel V, Peraste J, Petetin I, Lupo C, Le Bouquin S (2011): Factors associated with mortality of broilers during transport to slaughterhouse. Animal, 5, 287-293.
5. Dadgar S, Lee ES, Leer TLV, Classen HL, Crowe TG, Shand PJ (2011): Effect of acute cold exposure, age, sex, and lairage on broiler breast meat quality. Poult Sci., 90, 444-457.

6. Drain ME, Whiting TL, Rasali DP, D'Angiolo VA (2007): Warm weather transport of broiler chickens in Manitoba. I, Farm management factors associated with death loss in transit to slaughter. Can.Vet.J., 48, 76-80.

7. Ekstrand C (1998): An observational cohort study of the effects of catching method on carcase rejection rates in broilers. Animal Welfare, 7, 87-96.

8. Haslam SM, Knowles TG, Brown SN, Wilkins LJ, Kestin SC, Warriss PD, Nicol CJ (2008): Prevalence and factors associated with it, of birds dead on arrival at the slaughterhouse and other rejection conditions in broiler chickens. Br.Poult.Sci., 49(6), 685-696.

9. Knierim U, Gocke A (2003): Effect of catching broilers by hand or machine on rates of injuries and dead-onarrivals. Animal Welfare, 12, 63-73.

10. Moran ET, Bilgili SF (1995): Influence of broiler livehaul on carcass quality and further-processing yields. J. Appl. Poult. Res., 4, 13-22.

11. Nijdam E, Arens P, Lambooij E, Decuypere E, Stegeman JA (2004): Factors influencing bruises and mortality of broilers during catching, transport and lairage. Poult Sci., 83, 1610-1615.

12. Petracci M, Bianchi M, Cavani C, Gaspari P, Lavazza A (2006): Pre-slaughter mortality in broiler chickens, turkeys ans spent hens Under comercial slaughtering. Poult Sci., 85, 1660-1664.

13. Schwartzkopf-Genswein KS, Faucitano L, Dadgar S, Shand P, González LA, Crowe TG (2012): Road transport of cattle, swine and poultry in North America and its impact on animal welfare, carcass and meat quality: A review. Meat Sci., 92, 227-243.

14. Strawford ML, Watts JM, Crowe TG, Classen HL, Shand PJ (2011): The effect of simulated cold weather transport on core body temperature and behavior of broilers. Poult Sci., 90), 2415-2424.

15. Taylor NL, Fletcher DL, Northcutt JK, Lacy MP (2001): Effect of transport cage height on broiler live shrink and defecation patterns. J. Appl. Poult. Res., 10, 335-339.

16. Vecerek V, Grbalova S, Voslarova E, Janackova B, Malena M (2006): Effects of travel distance and the season of the year on death rates in broilers transported to poultry processing plants. Poult Sci., 85, 1881-1884.

17. Vieira FMC, Silvia IJO, Barbosa Filho JAD, Vieira AMC, Broom DM (2011): Preslaughter mortality of broilers in relation to lairage and season in a subtropical climate. Poult Sci., 90, 2127-2133.

18. Voslarova E, Janackova B, Vitula F, Kozak A, Vecerek $\mathbf{V}$ (2007): Effects of transport distance and the season of the year on death rates among hens and roosters in transport to poultry processing plants in the Czech Republic in the period from 1997 to 2004. Veterinarni Medicina, 52, 262-266.

19. Warriss PD, Bevis EA, Brown SN, Edwards JE (1992): Longer journeys to processing plants are associated with higher mortality in broiler chickens. Br.Poult Sci., 33, 201206. 
20. Warriss PD, Pagazaurtundua A, Brown SN (2005): Relationship between maximum daily temperature and mortality of broiler chickens during transport and lairage. Br.Poult.Sci., 46, 647-651.

21. Zhang L, Yue HY, Zhang HJ, Xu L, Wu SG, Yan HJ, Gong YS, Qi GH (2009): Transport stress in broilers: I. Blood metabolism, glycolytic potential, and meat quality. Poult Sci., 88, 2033-2041.
Geliş tarihi: 13.12.2013/ Kabul tarihi: 18.03.2014

Address for correspondence:

Assoc. Prof. Dr. Yllmaz Aral

Ankara University, Faculty of Veterinary Medicine,

Department of Animal Health Economics and

Management,

06110 Dışkapı, Ankara, Turkey.

e-mail:yaral@veterinary.ankara.edu.tr 